\title{
Hindu Fanaticism in British India: A Catalyst for Muslim Separatism?
}

\section{Belkacem BELMEKKI}

University of Oran, Algeria

\begin{abstract}
According to the late British scholar Barbara Ward, "nothing so concentrates one's national feeling as being aware of somebody else's." To put it differently, the feeling of national unity among a given group of people grows stronger if the said group is exposed to an outside threat. As an illustration, Ward gave the example of the French nation where, she thinks, the French became self-aware a long time ago as a result of the amount of time they spent fighting the English next door. ${ }^{2}$ Lending support to this argument, K. K. Aziz stated that "it is a commonplace observation that the solidarity of a group becomes especially marked when it is threatened by other groups which do not share its particular beliefs and sentiments."
\end{abstract}

In this article, an attempt will be made to examine the case of the Muslims of India under British rule, who, by the last quarter of the nineteenth century, came to realize the fact that they formed a separate nation. Hence, what prompted the "Mohammedans" - as usually referred to by some Western scholars - to develop a national feeling and claim a separate identity from the rest of the communities

1 Barbara Ward, Five Ideas that Change the World, W W Norton \& Company Inc., New York, 1959, p. 19.

$2 \quad$ Ibid.

3 K. K. Aziz, The Making of Pakistan: A Study in Nationalism, Chattos \& Windus, London, 1967, p. 150.

4 The term 'Muhammadan', which was a common appellation used by Westerners to describe a Muslim person, is regarded by C. Horrie and P. Chippindale as absurd. In fact, both authors believe that the use of 'the word 'Muhammadanism' was probably mistakenly used as a result of a confusion with Christianity or Buddhism which are both named after their founders, namely Christ and Buddha. Chris Horrie and Peter Chippindale, What is Islam?: A Comprehensive Introduction, Virgin Books, London, 2003, p. 27. 
inhabiting the Indian Sub-continent, notably the Hindus? In other words, can Barbara Ward's and K. K. Aziz's arguments above be applied to the Muslim case in British India?

Actually, many scholars and contemporaries of the late nineteenth and early twentieth century British India believe that the sentiment of separateness among the Muslim community there was, in the main, brought about by the fact that they the Indian Muslims - sensed a serious threat emanating from the overwhelming Hindu majority in the Sub-continent. This serious threat was, in fact, engendered by the political activities as well as the fanatical behaviour of some of the Hindu nationalists who were made responsible for the alienation of their Muslim fellow countrymen.

Indeed, the Hindu character of the newly born Indian nationalist movement, namely the Indian National Congress (1885), and the anti-Muslim activities of some of its Hindu leaders, did, in effect, play a significant role - to say the least in antagonizing the Indian Muslims. ${ }^{5}$ In the view of Verney Lovett, this was because these Hindu activists resorted to the stimulation of Hindu enthusiasm among the masses through the reviving of anti-Muslim Hindu festivals, which contributed significantly to the widening of the - already wide - breach between the Muslim and Hindu communities. ${ }^{6}$

For the sake of illustration, it is useful to mention the public festivals in honour of Shivaji, the famous Maratha Hindu hero, who had at a certain time in the past successfully fought against Muslim domination in the Sub-continent. ${ }^{7}$ In this regard, Vinod Kumar Saxena observed that Shivaji was to many Hindus a hero who struggled for freedom in the past; yet, to many Indian Muslims he was the "political opponent of the Muslim rule in India."8 Actually, during such festivals, which aroused a great deal of anger among the Muslim community, Hindu fanatics would chant the following verses:

... it is necessary to be prompt in engaging in desperate enterprises like Sivaji ...; knowing, you good people should take up swords and shields at all events now; we shall cut off countless heads of enemies. Listen! We shall shed upon the

5 Matiur Rahman, From Consultation to Confrontation: A Study of the Muslim League in British Indian Politics: 1906-1912, Luzac \& Company Ltd., London, 1970, p.5

6 Verney Lovett, Nationalist Movement in India, Akashdeep Publishing House, India, 1988, p. 47.

7 Ibid. According to V. Lovett, Shivaji was said to have killed a Muslim general named Afzal Khan, during a bloody confrontation between their respective troops. Ibid.

8 Vinod Kumar Saxena, Muslims and the Indian National Congress: 1885-1924, Discovery Publishing House, Delhi, 1985, p. 104. 
earth the life-blood of the enemies who destroy our religion; we shall die only, while you will hear the story ...9

Other anti-Muslim activities could be seen in the emergence of associations that called for the abolition of cow slaughtering. According to Peter van der Veer, the protection of gau mata, or mother cow, was one of the most serious issues broached among the Hindu community by the last quarter of the nineteenth century. ${ }^{10}$ Hindu nationalists were said to have demanded the British Colonial Government to put an end to such a practice, yet their demands were never satisfied. Consequently, this created a serious disagreement with the British authorities as well as the Indian Muslims. In fact, the latter were regarded by the Hindu community as "butchers" since they sacrificed the cow on the festival of Eid Al Adha, to celebrate Abraham's offering of his son Ishmael. ${ }^{11}$

In the meantime, Lawrence James asserted that the devout Hindus always regarded the act of cow-slaughtering as a 'matricide' - since the cow represented a universal mother for them. In such a condition, they felt duty-bound to protect her. ${ }^{12}$ As a result, this culminated on many occasions in inter-communal confrontations; as confirmed by Jim Masselos who pointed out that this cow protection Hindu militancy, which gained momentum during the mid nineties, led to intermittent outbreak of Muslim-Hindu sectarian riots throughout the whole Sub-continent. ${ }^{13}$

Probably the best known anti-cow slaughtering association was the Cow Protection Society, an open anti-Muslim association, which was founded in 1882 by a Hindu enthusiast called Swami Dayananda (1824-1883). ${ }^{14}$ The latter published a treatise entitled Gokarunanidhi (Ocean mercy to the cow), in which he vehemently opposed the slaughter of the mother cow and considered it as an anti-Hindu act; hence, Dyananda made cow protection a Hindu cause. ${ }^{15}$

It should be noted that the growing Hindu militancy in India was nurtured by the works of some "extremist" Hindu activists, and the most notable among these were Bal Gangadhar Tilak (1856-1920), Aurobindo Ghose (1872-1950) Lajpat Lala Rai

\footnotetext{
9 Quoted in, V. Lovett, op. cit., p. 48.

10 Peter van der Veer, Religious Nationalism: Hindus and Muslims in India, University of California Press, Berkeley (California), 1994, p. 86. Ibid.

12 Lawrence James, Raj: The Making and Unmaking of British India, Little, Brown and Company, London, 1997, p. 420.

13 J. Masselos, Indian Nationalism: An History, Sterling Publishers Private Limited, New Delhi, 1996, p. 131.

14 K. K. Aziz, op. cit., p. 80.

15 Peter van der Veer, op. cit., p. 91.
} 
(1865-1928), who, being impatient to throw off the yoke of foreign rule, wanted to build up mass support for their nationalist movement. ${ }^{16}$

According to Mushirul Hasan, these Hindu activists were of the view that the Hindu masses could only be aroused through revivalism as well as the use of religious symbols and national historical myths, such as the celebration of Hindu festivals. ${ }^{17}$ In this respect, Christophe Jaffrelot quoted Bal Gangadhar Tilak as saying that: "la fierté et l'admiration pour nos héros nationaux sont un élément majeur du sentiment national..." ${ }^{18}$ Sharing the same premise with Tilak, Aurobindo Ghose sought to forge an Indian nationalism that was largely Hindu, spiritually as well as traditionally, because he believed that the Hindu had created this country India - and this people and perpetuated the grandeur of its past, civilization and culture. ${ }^{19}$

Hence, this conviction led these Hindu extremists to fall into the trap of mixing religion with politics, a thing that gave a religious - i.e. a Hindu -, hence a communal, character to the Indian National Congress. For instance, about Bal Gangadhar Tilak, Mushirul Hasan stated that while recognizing his vital contribution to the anti-colonial struggle, it was hard to ignore his role in heightening communal consciousness in the Sub-continent. ${ }^{20}$ Meanwhile, K. K. Aziz claimed that Tilak felt that nationalism required a "spiritual base" which he provided from the "Hindu dogma". ${ }^{21}$

In a few words, Stephen Hay depicted the political philosophy of these Hindu nationalists in the following words:

This group ... drew on the newly formulated ideals of renascent Hinduism and created a potent ideology out of the marriage between these ideals and the imported concepts of patriotism and national unity. ${ }^{22}$

On the other hand, anti-Muslim activism among the Hindu community could also be reflected in the literary works done by some Hindu men of letters. For instance,

\footnotetext{
16 Stephen Hay (ed.), Sources of Indian Tradition, Volume II: Modern India and Pakistan, Penguin Books, New Delhi, 1992, p. 128.

17 Mushirul Hasan, Nationalism and Communal Politics in India: 1885-1930, Manohar, New Delhi, 2000, pp. 22-23.

18 Christophe Jaffrelot, 'L'émergence des nationalismes en Inde : Perspectives théoriques', in Revue française de science politique, Année 1988, Volume 38, Numéro 4 (555 - 575), p. 570.

19 Ibid.

20 Mushirul Hasan, op. cit., p. 23.

21 K. K. Aziz, op. cit., p. 102.

22 S. Hay (ed.), op. cit., p. 128.
} 
the works of Bankim Chandra Chatterjee, one of the greatest Hindu novelists during the second half of the nineteenth century, were fraught with anti-Muslim statements and ideas. According to K. K. Aziz, this Hindu novelist would always use the term "Hindu" as a synonym to the term "Indian", and used to depict the Indian Muslims as aliens, who had played the role of "oppressors and tyrants" in the Sub-continent. Moreover, the references made by Bankim Chandra Chatterjee to the Muslim community were "frequently sneers of contempt." 23

Consequently, this unfriendly "anti-Muhammedan" attitude made the leaders of the Muslim community and many of their co-religionists impugn the real intentions of the Hindus as well as their political organization, i.e. the Indian National Congress, whose founders claimed that it represented and spoke on behalf of the whole population of India. In addition to that, the Indian Muslims grew convinced of the fact that their interests would be compromised in the hands of this overwhelmingly Hindu political organization.

This led many Muslim leaders - prominent among whom was Sir Sayyid Ahmad $\mathrm{Khan}^{24}$ - to reject the many appeals made by the more moderate elements of the Congress to join their organization. In fact, in the wake of the establishment of the Indian National Congress, Sir Sayyid Ahmad Khan, who made no secret of his firm opposition to it, advised his co-religionists to keep aloof from this "pseudo" national movement, which he dubbed as the "Bengali Assembly", ${ }^{25}$ or the "Bengalis' Congress". ${ }^{26}$ In this respect, Shameem. H. Kadri pointed out:

He (Sir Sayyid Ahmad) never wavered in his opposition to the Congress and declared that even if he was told that the Viceroy, the Secretary of State and the whole House of Commons had openly supported the Congress, he would still remain firmly opposed to it, and he earnestly begged all Muslims to remain away from it. ${ }^{27}$

Here, it is worthwhile to mention the fact that besides the Hindu character of the Indian National Congress, the rationale behind Sir Sayyid Ahmad's firm opposition to the Indian National Congress was the fact that he could see through the real

$23 \quad$ K. K. Aziz, op. cit., p. 80.

24 Sir Sayyid (also Syed) Ahmad Khan (1817-1898), born of a well-off family, was a Muslim jurist, educator and author who entered the service of the East India Company as a clerk in the Judicial Department, and later rose to the position of sub-judge.

H. D. Sharma (ed.), 100 Best Pre-Independence Speeches: 1870-1947, HarperCollins Publishers India, New Delhi, 1998, p. 14.

26 Madhu Limaye, Indian National Movement: Its Ideological and Socio-economic Dimensions, Sangam Books, 1989, p. 141.

27 Shameem. H. Kadri, Creation of Pakistan, Wajidalis, Lahore, 1982, p. 12. 
danger behind its creation. Actually, this Muslim leader was of the opinion that the demands of this party, regarding the enlargement of the Legislative Council based on the system of representation by election, or the principle of one man one vote, if acceded to, would jeopardize the interests of the Muslims of India, given the fact that the latter were numerically smaller than the Hindu majority. As he set it out in the Imperial Legislative Council in 1883, that is, on the eve of the establishment of the Indian National Congress:

The System of representation by election means the representation of the views and interests of the majority of the population and in countries where the population is composed of one race and one creed, it is no doubt the best system that can be adopted. But, my Lord, in a country like India, ... where there is fusion of the various races, where religious distinctions are still violent, where education in it modern sense has not made an equal or proportionate progress among all the sections of the population, I am convinced that the introduction of the Principle of election ... for representation of various interests ... would be attended with evils of greater significance than purely economic considerations. So long as differences of race and creed ... form an important element in the sociopolitical life of India and influence her inhabitants in matters connected with the administration and welfare of the country ... the system of election ... cannot be safely adopted. The larger community would totally override the interests of the smaller community.$^{28}$

Besides, Sir Sayyid Ahmad's opposition to the introduction of the principle of election and universal suffrage was based on the premise that the majority of the inhabitants of India were illiterate and lacked the required education to exercise such a principle. In his view, the successful adoption of democratic principles and the implementation of a meaningful and genuine form of democracy become feasible only when India becomes a fertile land, where the native population attains a certain level of education required for that purpose. This led Sir Sayyid Ahmad to label the leaders of the Indian National Congress as "daydreamers". ${ }^{29}$

Moreover, this Muslim leader was convinced of the fact that India was not yet fit for Western political institutions which required thorough grounding in Western

28 Quoted in, R. Coupland, The Indian Problem: Report on the Constitutional Problem in India, Oxford University Press, New York, 1944, p. 155.

29 Tariq Hasan, The Aligarh Movement and the Making of the Indian Muslim Mind: 1857-2002, Rupa \& Co., New Delhi, 2006, p. 110. 
education that even the most advanced Hindus had not reached yet. In this regard, S. R. Wasti commented:

\section{For centuries ... India had been without politics or at least without any party politics, and a thorough grounding in western education was indispensable for any political understanding. ${ }^{30}$}

Consequently, this made Sir Sayyid Ahmad go so far as to reject the idea of setting up a Parliament in India. As he put it: "This is not the time for the grant of rights, and the idea of the establishment of a Parliament for India is absurd." 31

With regard to the Congress demand for the Indianization of Services and recruitment by competitive examination, Sir Sayyid Ahmad believed that it would by no means benefit his co-religionists since they were still backward in education, ${ }^{32}$ contrary to their Hindu counterparts who had already made steady progress in this sense. In this respect, many scholars claimed that Sir Sayyid Ahmad was driven to react by his fears for his community in case these demands were met. $^{33}$ To back up this statement, Richard Symonds cited this Muslim reformist as wondering: "Have the Mohammedans attained to such a position as regards higher English education which is necessary for higher appointments as to put them on a level with Hindus or not?" Then he concluded: "Most certainly not?"34

In addition to all that, Sir Sayyid Ahmad was, as pointed out by Hafeez Malik, convinced that even though solidarity and entente could be established between the Muslim and Hindu communities in the educational and cultural spheres, it would be impossible to think of a context where both communities would share equally the sovereignty of India after the hypothetical withdrawal of the British. In fact, the withdrawal of the British rulers, in the mind of Sir Sayyid Ahmad, would only

\footnotetext{
30 S. R. Wasti, Lord Minto and the Indian Nationalist Movement: 1905-1910, Lord Minto and the Indian Nationalist Movement: 1905-1910, Clarendon Press, Oxford, 1964, p. 6.

31 Quoted in, Muhammad Y. Abbasi, The Genesis of Muslim Fundamentalism in British India, Eastern Book Corporation, New Delhi, 1987, p.72.

32 Shun Muhammad (ed.), The Aligarh Movement: Basic Documents: 1864-1898, Meenakshi Prakashan, Meerut, 1978, p. xxiv.

33 Sir Sayyid Ahmad's fears where shared by many members of his community, and this could be seen in the 1890 petition presented to the House of Commons in London, which was signed by almost 40,000 Muslims from seventy different cities and towns in the Sub-continent, in which they pleaded with the Colonial authorities to not introduce the principle of election into the constitution of the Indian Councils as requested by the Indian National Congress. K. K. Aziz, Britain and Pakistan: A Study of British Attitude towards the East Pakistan Crisis of 1971, University of Islamabad Press, Islamabad, 1974, p. 10. 
create a "vacuum of power", which would eventually culminate in a "struggle for hegemony between the two contenders, Hindus and Muslims." 35 As a result, this Muslim leader urged the Muslims of India to depend on the British, or - as he called them - the People of the Book, ${ }^{36}$ to safeguard their interests and that in the absence of the latter, the Hindus would conquer them. ${ }^{37}$ As confirmed in the following excerpt from one of his speeches:

Now suppose that all the English ... were to leave India ... then
who would be the rulers of India? Is it possible that under these
circumstances two nations - the Mohammedans and the Hindus
- could sit on the same throne and remain equal in power?
Most certainly not. It is necessary that one of them should
conquer the other and thrust it down. ${ }^{38}$

Apart from that, another significant factor, probably the most significant one, that alienated the Muslim community and, hence, contributed to Muslim separatism in British India, was the furore that the Hindu activists orchestrated during the 1900's in reaction to Lord Curzon's scheme to partition the province of Bengal ostensibly for administrative convenience. ${ }^{39}$ In fact, the partition of Bengal, which resulted in the creation of a new province where the Muslims made up the majority, was vigorously opposed by the Congress leaders, who immediately sought its reversal.

In other words, whereas the Indian Muslims hailed Lord Curzon's initiative, since the partition was beneficial to them, the Hindus were angered by such a "vivisection of the Bengali heartland" 40 which they described as "preposterous". ${ }^{41}$

35 H. Malik, 'Sir Sayyid Ahmad Khan's Contribution to the Development of Muslim Nationalism in India', in Modern Asian Studies, Vol. 4, No. 2, Cambridge University Press, 1970, (129-147), p. 144.

36 Sir Sayyid Ahmad exhorted his co-religionists to side with the 'People of the Book' - as Christians are referred to in the Holy Quran - rather than with the Hindus. He believed that Islam was nearer to Christianity than any other religion in the world, and that it had more in common with the monotheism of Christianity than the polytheism of Hinduism. K. K. Aziz, The Making of Pakistan: A Study in Nationalism, op. cit., p. 70.

37 M. Limaye, op. cit., p. 142.

38 Sir Sayyid Ahmad Khan, 'One Country, Two Nations', in H. D. Sharma (ed.), op. cit., p. 20.

39 The argument behind Lord Curzon's move to partition the province of Bengal was that he believed that it was too large, and hence, too unwieldy to be administered by one lieutenantgovernor, hence, the necessity of dividing it into two manageable provinces. K. K. Aziz, The Making of Pakistan: A Study in Nationalism, op. cit., p. 24.

$40 \quad$ Ibid., p. 25.

41 B. Chandra, A. Tripathi and B. De, Freedom Struggle, National Book Trust, New Delhi, 1983, p. 85 . 
As a reaction, they conducted a vigorous agitation which took a new turn by giving birth to a boycott movement, usually referred to as the swadeshi movement. ${ }^{42}$

Surjit Mansingh defined the term swadeshi as literally meaning "one's own country" ${ }^{43}$ Therefore, in the context of colonial India, the swadeshi movement aimed at boycotting British goods, and using Indian-made goods instead, in order to force the British Colonial Government to revoke the partition scheme. ${ }^{44}$ About this boycott campaign, the Hindu activist Lajpat Rai stated that the British attention would only be drawn to the grievances of the Indian population by "directly threatening their pockets." ${ }^{45}$ Thus, in a word, the swadeshi movement was to be used as an economic weapon to force the colonial administration to reconsider Lord Curzon's plan.

The Indian Muslims, meanwhile, interpreted this Hindu "overreaction" to Lord Curzon's boundary reorganization as a clear indication that they - the Hindus wanted to keep the pre-partition status quo in Bengal, whereby the Hindu community would continue holding the upper hand in all spheres of life. ${ }^{46}$ In this regard, K. K. Aziz affirmed that in pre-partition eastern Bengal, the Hindus, who made up but a minority of the population of the region, used to hold ten times as many appointments as the Muslims, and additionally, five times as many Hindus held judicial positions. ${ }^{47}$

To make matters worse, the anti-partition agitation per se took a religious colouring that could by no means appeal to the Muslims. According to Bipan Chandra et al., on the day partition was to be implemented, a general hartal ${ }^{48}$ was

42 The swadeshi movement was declared on 7 August 1905 following a meeting of the Indian National Congress held at the Calcutta town hall. B. Chandra, M. Mukherjee, A. Mukherjee, K. N. Panikkar and S. Mahajan, India's Struggle for Independence, Penguin Books, New Delhi, 1989, p. 127.

43 Surjit Mansingh, Historical Dictionary of India, The Scarecrow Press Inc., Lanham, Maryland, 1996, p. xx. in India, S. R. Wasti (ed.), Renaissance Publishing House, Delhi, 1993 (67-73), p. 70. Romesh Chunder Dutt (1848-1909), a Hindu scholar, during one of his lectures stated that the "essence of the (swadeshi) scheme ... is by every lawful method, to encourage, and foster home industries, and to stimulate the use of home manufactures among all classes of people in India." R. C. Dutt, 'The Industrial Development of India', in H. D. Sharma (ed.), op. cit., p. 71.

45 B. Chandra, A. Tripathi and B. De, op. cit., p. 88. in the same respect, Bipan Chandra et al. quoted Bal Gangadhar Tilak and his companions talking about the swadeshi movement as being: "an economic pressure on Manchester, a weapon of political agitation against imperialism and a training in self-sufficiency for the attainment of 'swaraj'." Ibid. The Hindi word 'swaraj' literally means self-rule or independence. Ibid., p. 26. 
organized, and many people fasted - "no fires were lit at the cooking hearths" and walked barefooted towards the Hindu holy river, the Ganga, in order to take a bath as a ritual practice. ${ }^{50}$ Besides, while en route to the Ganga River, these Hindu activists were chanting some patriotic songs, such as Bande mataram. ${ }^{51}$

For the sake of clarity, it is worthwhile to note the fact that the Bande mataram $^{52}$ song was a Hindu revolutionary poem which invoked divine assistance against the foreign intruders, namely the Muslims and the British, and which urged the members of the Hindu community to drive them both out of the Indian Subcontinent. ${ }^{53}$ In this regard, Vinod Kumar Saxena affirmed that Bande Mataram appeared offensive to many Muslims because its verses were "taken to exalt Hinduism at the expense of Islam." ${ }^{54}$

In the meantime, K. K. Aziz observed that this song, which was distasteful to the Muslims of India, was made a sort of national anthem by the Congress leaders and was sung during all their meetings. ${ }^{55}$

Furthermore, the lyrics of this song had a religious connotation. According to Hans Kohn, the term "mother" refers to the country, and the "mother country" was identified with divinity. In addition, Hans Kohn pointed out that the "mother country" was, in fact, a synthesis of all the gods that were worshipped by the Hindus. ${ }^{56}$ Hence, the idea of worshipping the motherland as a deity was an anathema to the Muslims since Islam states that there is only one God to be worshipped, Allah. ${ }^{57}$

Thus, it is important to note that the Indian Muslims could, probably, have taken part in the boycott movement, had it not had "strong religious colouring which attracted the Hindu masses." ${ }^{58}$ In fact, in the opinion of Akshayakumar R. Desai, the Hindu ideology into which the Congress leader, and the radicals in particular, clothed nationalism by the end of the nineteenth and beginning of the twentieth

48 'Hartal' is a Hindi word meaning the suspension of business or work as a form of protest. Surjit Mansingh, op. cit., p. xvi.

49 B. Chandra, M. Mukherjee, A. Mukherjee, K. N. Panikkar and S. Mahajan, op. cit., p. 127.

50 B. Chandra, A. Tripathi and B. De, op. cit., p. 87.

$51 \quad$ Ibid.

52 Bande mataram (literally meaning 'Hail to thee, Mother') was taken from Bankim Chaterjee's anti-Muslim novel entitled Anandamath. Anthony Read and David Fisher, The Proudest Day: India's Long Road to Independence, Pimlico, London, 1998, p. 91.

53 K. K. Aziz, The Making of Pakistan: A Study in Nationalism, op. cit., p. 82.

$54 \quad$ Vinod Kumar Saxena, op. cit., p. 104.

55 Ibid.

56 Hans Kohn, A History of Nationalism in the East, Harcourt Brace \& Co., London, 1929, p. 382.

57 A. Read and D. Fisher, op. cit., p. 91.

58 S. R. Wasti, 'Partition of Bengal and its Immediate Effects', op. cit., p. 70. 
centuries, could not appeal to the sentiments of the politically conscious Muslim middle classes. In this regard, Shameem. H. Kadri contended that the anti-partition agitation "appealed to Hindu religious antipathy against the Muslims."

Indeed, the vigour with which the Hindu reacted to the partition plan had impressed to a great extent the Muslim community of India. In their eyes, this was a clear proof that the Indian National Congress's alleged claim that it stood for the Hindu-Muslim unity was but a set of demagogic words used by the leaders of this political party to win over Muslim support. In fact, the anti-partition agitation exposed to the Indian Muslims the real intentions of the Hindus and, in addition, the fact that the latter opposed the establishment of a Muslim majority province showed every indication that the Muslim interests could by no means be protected at the hands of the Hindus. Therefore, in such an atmosphere, could the Muslim community expect any fair-play from the Hindu majority?

To sum it all up, Muslim nationalism in British India was born as a result of the fear of insecurity that prevailed among the Muslim community there as a result of the extremist comportment of many Hindu activists. In fact, the fanatical behaviour of Bal Gangadhar Tilak, Aurobindo Ghose, Lajpat Lala Rai, and the other likeminded Hindu enthusiasts, who were taken by their religious zealotry, did everything except gain the confidence of their Muslim fellow countrymen. This fact was confirmed by Mushirul Hasan who commented that the "coalition between religious conservatism and political extremism hindered their - i.e. Hindu activists' - mobilization." ${ }^{\circ 9}$

In other words, the Hindu character of the Indian National Congress, which marked the beginning of Hindu-Muslim friction, or rather, brought to the fore the already existing friction between both communities, had only alienated the Muslim nationalist leaders, who, growing anxious, realized the necessity of setting up a Muslim organization on an all-India basis, that would be capable of uniting the Muslims of India and defending their interests.

Therefore, this confirms Barbara Ward's and K. K. Aziz's argument that the feeling of fear and outside threat plays an important role in strengthening solidarity among a group of people. In addition to that, being much more acquainted with the circumstances in the Indian Sub-continent, K. K. Aziz pointed out that the national feeling always thrives on opposition, and as a result, the more it is crushed, the stronger it becomes. Consequently, K. K. Aziz concluded, that feeling of

59 Mushirul Hasan, op. cit., pp. 23-24. 
separateness among the Indian Muslims received an impetus from the vigorous Hindu opposition to it. ${ }^{60}$

To put it all in a nutshell, the Hindu nationalists rendered a great service to those elements of the Muslim society in India who sought to form an independent Muslim state. In fact, the impetus that the Muslim nationalist movement received from the Hindus not only did it lead to the formation of the first permanent Muslim political party - i.e. the All-India Muslim League - by the year 1906, but also to the creation, four decades later, of the first Muslim state in the Indian Subcontinent, Pakistan. As put by the same scholar, who remarked that:

... the Muslims owed the creation of Pakistan to the Congress, in the sense that had the Congress treated the Muslims differently there would have been no Muslim separatism and therefore no Pakistan. ${ }^{61}$

\title{
Summary
}

\section{Hindu Fanaticism in British India: A Catalyst for Muslim Separatism?}

\author{
Belkacem BELMEKKI \\ University of Oran, Algeria
}

\begin{abstract}
A great deal of research has been devoted to the explanation of the phenomenon of Muslim separatism/communalism in British India. In the main, scholars have been divided between, on the one hand, the Primordialists (such as Francis Robinson) who argued that this separatist tendency was an inevitable corollary pre-ordained from pre-modern times given the fundamental distinctions between the Muslim culture and the Hindu one, and on the other hand, the Instrumentalists (such as Paul Brass), who saw in this separatism nothing more than a stratagem orchestrated by the Muslim elite in order to safeguard their interests. This article, however, is an attempt to look at Muslim separatism from a different angle, that of fear of the Hindu majority.
\end{abstract}

Keywords: Muslim separatism, Hindu fanaticism, British India, religion and politics

\footnotetext{
${ }_{60} \quad$ K. K. Aziz, The Making of Pakistan: A Study in Nationalism, op. cit., p. 209.

61 Ibid., p. 184.
} 